https://doi.org/10.18232/20073496.1221

Artículos

\title{
El origen del capitalismo de amigos latinoamericano actual: la operación de redes de intereses e instituciones clave en el periodo colonial
}

\section{The Origin of Current Latin American Crony Capitalism: The Operation of Networks of Interests and Key Institutions in the Colonial Period}

José Galindo 1, * (D) 0000-0002-7645-053X

${ }^{1}$ Universidad Veracruzana, Xalapa, México.

*Correspondencia: josgalindo@uv.mx

Resumen. Este artículo reflexiona sobre el origen de la corrupción colusiva, término contemporáneo que vincula a empresarios y políticos por medio de la formación de redes y que bajo algunos escenarios es sinónimo de capitalismo de amigos. Se estudian características y particularidades de las redes de intereses desde fines del periodo colonial, así como su peso en limitar intentos por reformar instituciones específicas de Nueva España y otros virreinatos de la corona española. La tesis del artículo es que las prácticas coloniales que llevaron a la formación de redes entre comerciantes y gobernantes asentaron un precedente para el capitalismo de amigos de la actualidad. Para ello, en el artículo se contrastan hallazgos y afirmaciones de diversas fuentes debidamente contextualizadas. El artículo concluye con elementos que permiten repensar el tema de la continuidad de las prácticas de colusión hasta el presente.

Palabras clave: corrupción colonial; capitalismo de amigos; corrupción colusiva; redes de intereses; redes sociales; Latinoamérica.

CÓMO CITAR: Galindo, J. (2021). El origen del capitalismo de amigos latinoamericano actual: la operación de redes de intereses e instituciones clave en el periodo colonial. América Latina en la Historia Económica, 28(3), 1-24. DOI: 20073496.1221 
Abstract. This article reflects on the origin of collusive corruption, a contemporary term that in its definition links entrepreneurs and politicians through the formation of networks and that, under certain scenarios, it is synonymous with crony capitalism. It studies the characteristics and particularities of these networks specifically since the late colonial period, as well as their weight in limiting attempts to reform specific institutions in New Spain and other viceroyalties of the Spanish Crown. The main thesis of the article is that the colonial practices that led to the formation of networks between merchants and rulers set a precedent for today's crony capitalism. For this, the article contrasts findings and affirmations of diverse duly contextualized sources. The article concludes with elements that allow us to rethink the continuity of collusive practices until today.

Key words: colonial corruption; crony capitalism; collusive corruption; interest networks; social networks; Latin America.

JEL: N46; N86; N96.

Recibido: 15 de noviembre de 2019.

Aceptado: 07 de diciembre de 2020.

Publicado: 19 de julio de 2021.

Agradecimiento: Quiero agradecer especialmente a Diana Citlalli Méndez Hernández por su labor como asistente en la elaboración de este artículo.

\section{INTRODUCGIÓN}

Existe una serie de temas específicos que ha tenido un peso sustantivo en la definición actual tanto de los aparatos legales como desarrollos institucionales formales e informales en los países que conforman la región latinoamericana. Uno de ellos es el fenómeno de la corrupción. Aunque la definición de corrupción es un tema complejo y amplio, muchos estudios científicos definen la corrupción como el abuso de un puesto público para obtener un beneficio privado.

A pesar de la aparente simplicidad de esta definición, el significado de los términos se vuelve complicado, porque su sentido, para algunos autores, depende del contexto histórico donde ha surgido, lo que ha dado lugar a diferentes debates. Esto mismo sucede con las explicaciones sobre el surgimiento de los diferentes cuerpos legislativos a lo largo de la historia. Entre las tesis se encuentra la de Harold J. Berman (2001), quien defendió la idea de que las leyes y sus reglas sólo tienen sentido en el contexto, mentalidad, valores, modos e instituciones en la cual surgieron. Así, el estudio del tema de que la corrupción en la época colonial también tiene diferentes significados para muchos estudiosos.

Entonces, a partir del concepto de corrupción se han desarrollado diversos y numerosos trabajos. Para el caso del estudio de la corrupción sobre la Hispanoamérica colonial, Horst Pietschmann (1998, p. 39) afirma que el interés en el tema floreció después de la segunda guerra mundial, y a partir de ahí se empezó por primera vez con una revisión sistemática de los grandes repositorios de fuentes que existían tanto en España como en América. A partir de 1970 se empezó a discutir ${ }^{1}$ que la corrupción no era un abuso en sí, sino que formaba parte de un sistema de aceptación que incluía a la corona. En ese momento se debatía sobre la venta de nombramientos en cargos públicos que, debido a los bajos sueldos que los caracterizaban, más bien se utilizaban con el objeto de

${ }^{1}$ Pietschmann menciona dos trabajos importantes que surgieron a partir de esa discusión de la década de 1970; estos trabajos son: Kenneth Andrien (1984, pp. 1-20), y Horst Pietschmann (1982, pp. 11-37). 
favorecer los intereses de todos los involucrados en esas ventas. A raíz de estas acciones, se concluyó que la corrupción cumplía una función política y equilibraba intereses entre la corona y las sociedades de la colonia. Ya para finales de la década de 1970 y principios de $1980^{2}$ se originaron nuevas investigaciones analizando profundamente las relaciones entre las elites y la burocracia, sus influencias e intereses. Este tipo de investigaciones se siguen desarrollando hasta la actualidad (Pietschmann, 1998, pp. 44-52).

Por otra parte, Francisco Andújar Castillo y Pilar Ponce Leyva (2018), a partir de investigaciones realizadas en los últimos años, sostienen que actualmente hay tres perspectivas de estudio de la corrupción en el antiguo régimen. La primera, es aquella en la que la corrupción es vista por los investigadores (véase Carrasco, 2018) como una práctica tolerable de la época; en la segunda, los estudiosos del tema (véase Ragon, 2018, pp. 17-30) utilizan el término "corrupción" sin sumergirse en el estudio de las prácticas ilícitas, y la tercera, es la que utiliza el término para “referirse a las múltiples prácticas que ayer y hoy se vinculan con el término 'corrupción', como los sobornos y los excesos" (Andújar y Ponce, 2018, pp. 11-12). Algunos de estos trabajos están enfocados en la corrupción que había desde los reyes, virreyes, miembros del clero, personas cercanas al rey, militares, y más miembros de la sociedad colonial. Estos estudios (véase Córdoba, 2018, pp. 229-239) se enfocan en actividades como fraude, contrabando, abuso de poder, actividades que se realizaron tanto en España como en las colonias, aunque principalmente en las colonias debido a la mayor posibilidad de enriquecimiento ante la falta de supervisión directa y la existencia de abundantes áreas de oportunidad, incluidos los recursos naturales. También hay diferentes trabajos que se encargan de estudiar las medidas aplicadas para combatir la corrupción, como los trabajos de Amorina Villarreal Brasca (2018), o los que se dedican a estudiar la corrupción en un tiempo determinado como Francisco Andújar Castillo (2019) y sus estudios sobre el siglo XVII, por mencionar algunos autores.

Además, están los trabajos con orientación neoinstitucionalista, en los que la corrupción se incluye como un balance económico más que como expresión de la cultura política. Dentro de este enfoque están los trabajos generales de Douglass North y Robert Thomas (1973) que incluyen estudios enfocados en la colonia, y otros que hacen referencia a una época más contemporánea que derivan de North (1990) sobre la definición de las instituciones. Stephen Haber (2002) también utiliza el enfoque neoinstitucionalista para estudiar a América Latina, aunque sus trabajos más influyentes de principios del año 2000 se enfocan principalmente en la segunda mitad del siglo xIx y la primera del xx.

Los trabajos de North (1990) y Haber (2002) han influido en la escritura del tema de la corrupción en redes o colusiva (vinculada a lo que hoy se conoce como capitalismo de amigos), tanto para el periodo colonial como para el periodo de la América Latina independiente. Existen estudios de autores latinoamericanos que hacen aportaciones dentro de esta escuela, entre ellos Luis E. Fajardo (2002), quien analiza cómo la falta de instituciones formales consolidadas en el periodo colonial llevó a los comerciantes de Cartagena a comprar puestos para establecer su propio sistema de justicia. Aunque más adelante expondremos este caso con profundidad, el que el estudio se refiera a instituciones formales poco consolidadas muestra una clara influencia de los estudios

${ }^{2}$ Algunos trabajos que menciona Pietschmann que se realizaron durante está temporalidad son: Hermes Tovar (1982, pp. 39-77) y Annino von Dusek, Castro Leiva y Guerra (1994). 
de Haber para finales del siglo XIx, en los que argumenta que la falta de instituciones formales o instituciones formales confiables es el detonante de la formación de las redes y el capitalismo de amigos.

También existen los estudios que tienen específicamente un enfoque cultural sobre la corrupción colonial, aquellos según los cuales la corrupción está determinada culturalmente, como la mayoría de los estudios que han elaborado Christoph Rosenmüller y Stephan Ruderer (2016). Sin embargo, los estudios que tienen un enfoque cultural sobre la corrupción no logran explicar los intereses y factores institucionales que yacen en el centro de las causas y consecuencias de la corrupción. En este sentido, en este artículo se considera que el aspecto económico es fundamental de considerarse en los estudios de corrupción, pues la mayoría de los beneficios directos e indirectos que se obtienen de la corrupción son económicos. Finalmente, existen varios estudios (véase Nye, 1967, pp. 417-427) con diferentes enfoques que utilizan definiciones de corrupción que emplean elementos que caracterizan a la corrupción contemporánea, y las intentan aplicar en el estudio de la corrupción colonial no siempre de manera acertada, sin tomar en cuenta elementos contextuales importantes que caracterizan a ese periodo ni un marco de referencia adecuado para esos años y, por tanto, cayendo muchas veces en un anacronismo, como es el caso del trabajo de Ismael Jiménez (2019) que estudia la corrupción de Perú.

De manera general, el estudio de la corrupción actual toma los elementos del contexto presente, incluido el marco legal, y se enfoca en dos grandes vertientes: corrupción extorsiva, que se refiere a aquella en la que los servidores públicos extorsionan haciendo su trabajo condicionalmente a cambio de regalos o dinero, y la corrupción colusiva, que implica la colusión entre diferentes actores de distinta jerarquía de los sectores público y privado. En este caso, los servidores públicos desvían o hacen mal uso del presupuesto público a través de vínculos estrechos entre empresas y políticos. Estos vínculos hacen que se logren con éxito muchos negocios, y que los funcionarios gubernamentales obtengan a cambio parte de las ganancias producto de los negocios. El origen de esta práctica, que puede clasificarse como capitalismo de amigos, se remonta al origen mismo del capitalismo. ${ }^{3}$ En este tipo de corrupción, el aspecto económico es fundamental. Es decir, es un mecanismo en el que se enriquecen tanto los políticos como sus amigos empresarios, quienes proveen bienes, servicios y obra pública al gobierno generalmente por medio de contratos gubernamentales que les son otorgados en condiciones favorables. El estudio del concepto de capitalismo de amigos es profundizado por la escuela neoinstitucionalista.

El esfuerzo que se realiza en este texto es el de vincular y reflexionar sucintamente sobre estudios culturales y económicos de la corrupción colonial para mostrar que aunque el capitalismo de amigos es un término contemporáneo, existieron situaciones en el pasado colonial tardío que ante

\footnotetext{
${ }^{3}$ No todo el capitalismo de amigos es necesariamente corrupto. Andrew Paxman distingue entre dos etapas o tipos de relaciones entre empresarios y funcionarios públicos: el imperativo simbiótico, que implica relaciones de "amiguismo" pero beneficia la formación del Estado y la estabilidad económica, por ejemplo, después de una revolución; y la conveniencia simbiótica, la que implica un interés económico personal mutuo, sin tener en cuenta a nadie más. Dicho de otra manera, toda la corrupción colusiva siempre implica capitalismo de amigos, pero no todo el capitalismo de amigos es necesariamente corrupto (Paxman, 2017, pp. 30-31). Semejante argumento se puede aplicar para algunas prácticas llevadas a cabo durante el periodo colonial, en donde las redes desempeñaron un papel en el fortalecimiento de procesos económicos particulares que simplificaban, por ejemplo, el comercio (véanse ejemplos más adelante). Sin embargo, siempre con la consecuencia de que aquellos que no pertenecían a esa(s) red(es) eran automáticamente excluidos de los beneficios de estos procesos; eso sí, dentro de una sociedad que de inicio era y buscaba ser corporativa y jerárquica, y, por tanto, excluyente de origen. Para una explicación detallada sobre cómo la corrupción colusiva se relaciona con el capitalismo de amigos, véase Galindo (2021).
} 
los excesos y dentro de un contexto de profundos cambios ideológicos se adecuan a este esquema de corrupción. ${ }^{4}$ Esto nos lleva a plantear las siguientes preguntas: si el origen del capitalismo de amigos se remonta desde el origen mismo del capitalismo, ca partir de cuándo el capitalismo ha estado presente en el continente americano?, ¿qué tipo de situaciones surgieron en la colonia tardía que nos permiten ejemplificar a comerciantes y servidores públicos manejando situaciones para beneficio, tipo "capitalismo de amigos", ante el cambiante entorno ideológico?, ¿̇cuáles fueron las condiciones que hicieron que los comerciantes fueran adquiriendo mayor poder? y, ¿̇cuáles fueron las consecuencias de este tipo de prácticas? Estas preguntas se intentarán responder analizando algunos estudios de casos de comerciantes en los que de manera independiente se ha profundizado en los temas expuestos, así como el contexto histórico.

\section{EL CAPITALISMO EN LOS VIRREINATOS DE LA CORONA ESPAÑOLA: CONTEXTO, INSTITUCIONES Y PRÁCTICAS HEREDADAS}

El peso de la influencia colonial en el desarrollo de diversos ámbitos como el social, religioso, político y económico en los países de América Latina ha sido notorio. ${ }^{5}$ Es por ello que, para poder entender diversas prácticas del presente, es necesario irnos a sus orígenes, su contexto y cómo se desarrollaron.

Existe un desacuerdo general entre los historiadores sobre el comienzo preciso del capitalismo, lo que según Angus Maddison (1986, p. 27) se debe a los niveles de crecimiento económico de las regiones y las teorías de etapas de crecimiento económico que los explican. Para Jürgen Kocka (2016), uno de los principales estudiosos del capitalismo en la actualidad, los primeros indicios del capitalismo estuvieron en el comercio y se pueden situar entre los siglos VII al Xv en China, Arabia y Europa; sin embargo, fue hasta 1500 que se adoptó una forma de capitalismo mercantil o comercial más definido principalmente en Europa, que fue una plataforma para el desarrollo del capitalismo moderno en el siglo XVIII. Entonces, entre los siglos XVI al XVIII se llevó a cabo el proceso de gestación de los principales centros capitalistas en Europa gracias al intercambio económico que se había expandido por el desarrollo del comercio y la abundancia de metales preciosos en circulación en el que participaban mercaderes o comerciantes, quienes por la misma riqueza acumulada fueron convirtiéndose en una fuerza económica y social que tuvo que ser tomada en cuenta en el propio gobierno de las ciudades. Este periodo es conocido como capitalismo mercantil (Borchart de Moreno, 1984, p. 15) y se caracterizaba por ser un sistema en el que el manejo de la producción y las ganancias resultantes estaban en manos de estos comerciantes (Mauro, 1955, p. 117).

Al profundizar en las ideas sobre el origen del capitalismo en España y en la región que hoy conforma Latinoamérica, Enrique Semo (1985) afirma que:

Las relaciones capitalistas estaban presentes en la España del siglo Xvi, pero se trataba de un capitalismo temprano, que se consolidaría a finales del siglo xviII en Inglaterra con la revolución industrial [...] España transmitirá a América las instituciones, y sobre todo, un capitalismo embrionario que no logra romper con las trabas feudales y se

${ }^{4}$ El concepto lo crearon periodistas estadunidenses en 1981, con la finalidad de describir la influencia de grupos de empresas políticamente favorecidas en Filipinas, y durante la crisis asiática de finales de la década de 1990 se utilizó ampliamente para calificar los arreglos dudosos entre elites que al parecer debilitaron las economías de Corea del Sur y Japón. W. Safire, “On language; crony capitalism”, The New York Times Magazine, 1 de febrero de 1998, p. 1.

${ }^{5}$ Véase Adelman (1999) para estudios que abordan específicamente los legados coloniales en diversos ámbitos de la vida independiente de los Estados-nación que surgieron posteriormente al periodo colonial. 
ve forzado adaptarse a ellas, o mejor dicho, a integrarse en ellas y por estos escenarios no logra crear las condiciones necesarias para una revolución industrial y con ello el triunfo definitivo del capitalismo (p. 128).

En España el Estado era controlado por una pesada burocracia corporativa jerárquica y por monopolios privados buscadores de rentas (North y Thomas, 1973, p. 31). Esto generaba inflexibilidad técnica y organizativa en el aparato burocrático y productivo español, así como gran cantidad de obstáculos jurídicos y escalones sociales que afectaban la operación y limitaron las condiciones que hubiesen permitido desarrollar el capitalismo de manera más efectiva en las colonias (Peña, 1991, p. 17).

Nueva España inicia este capitalismo embrionario dentro de una estructura colonial también inflexible heredada de España y con relaciones de dominio rígidas. Por ejemplo, pese a la eventual destrucción del sistema despótico-tributario indígena, esto no derivó en que eliminaran rasgos arcaicos de las relaciones sociales internas de la sociedad novohispana, como la continuidad de una comunidad explotada por otra. Además, la producción colonial se asentó en rasgos señoriales de un feudalismo en franco retroceso dentro del marco del colonialismo internacional. Estas características crearon un sistema mixto donde existían por un lado elementos de explotación laboral y, por otro, prácticas mercantilistas de explotación, sobre todo minera y ganadera de corte más avanzado (Peña, 1991, pp. 231-232). Estas condiciones crearon dos tendencias: $a$ ) formas organizativas favorables al capitalismo, y $b$ ) sistemas como la encomienda ${ }^{6}$-que terminó por ser señal de decadencia de las estructuras coloniales y señoriales-, la cual fue el efecto de las inflexibles estructuras coloniales, que impidió el desarrollo de las fuerzas productivas al ritmo capitalista que otras naciones europeas -como Inglaterra- estaban mostrando.

España también transmitió a sus colonias un sistema legal de una tradición diferente al que se implementó en las colonias europeas de Norteamérica. En Estados Unidos y Canadá el sistema jurídico derivó de la tradición anglosajona heredada por los ingleses: common law (derecho común). En cambio, en la mayor parte del resto del continente americano, la tradición jurídica derivó de aquella conocida como derecho continental, que a su vez fue influenciada por el derecho romano, germano y canónico, así como por las ideas de la Ilustración. Tanto el derecho continental como el derecho común compartieron características. Aunque en ambos el derecho canónico tuvo influencia, en el derecho común el derecho canónico perdió peso con la ruptura de Enrique VIII con la Iglesia católica. Otra similitud entre ambos tipos de derecho fue que los dos tuvieron como una de sus fuentes al Código de Justiniano, la más importante recopilación de leyes del derecho romano. Aquí, la herencia de la jurisprudencia, así como las costumbres de los antepasados, fueron elementos clave en la aplicación de las dos tradiciones legales (Moranchel, 2017; Morineau, 2003). Además, ambos tipos de derecho compartieron similitudes al momento de aplicarse en el continente americano. Los dos fueron empleados en territorios desconocidos con marcadas diferencias con España e Inglaterra, además de que se aplicaron con pluralidad debido a la diversidad de los grupos poblacionales (Elliott, 2006, p. 225).

Sin embargo, el sistema de derecho común logró consolidarse sobre la pluralidad de los sistemas legales que había en la América inglesa en parte por su resolución de disputas específicas que sentaron precedentes y referencias para fallos posteriores y acercaron el derecho más direc-

${ }^{6}$ Sistema de trabajo que a grandes rasgos consistía en la asignación de indígenas a españoles conquistadores, a quienes eran encomendados para su protección, educación y evangelización y quienes a su vez los utilizaban como mano de obra. 
tamente y de manera más pragmática a la realidad existente. Entonces, la base de este sistema legal anglosajón es este tipo de jurisprudencia, lo que difiere del derecho continental en donde la jurisprudencia no tuvo (ni ha tenido) la fuerza suficiente y sólo quedó como una fuente más de derecho. $^{7}$

En cuanto a la aplicación del derecho en el tema económico, en los países que emplean el derecho común la jurisprudencia ha permitido generar expedientes y fallos muy precisos sobre situaciones que ocurren en la práctica y relaciones capitalistas. Es decir, el derecho anglosajón tiene la característica de ir sumando a su cuerpo de leyes una serie de aspectos que le da un carácter práctico y específico a su operación. Estas características son fundamentales para resolver aspectos puntuales de las problemáticas más comunes en el desarrollo del sistema capitalista. Por ejemplo, la resolución de disputas comerciales, que llevan a la reducción de costos de transacción al garantizar los derechos individuales de propiedad privada. Esta es una característica fundamental para la expansión y la impersonalización de las transacciones comerciales capitalistas de gran escala, lo que incluye la inversión en capital físico y financiero.

Además, a finales del siglo xviII, cuando la idea y decisión de erradicar la corrupción -y, más adelante, las prácticas monopólicas- se concentraron más sólidamente entre los legisladores y pensadores ingleses y estadunidenses, influyendo en la redacción de la Constitución estadunidense, el sistema del common law ayudó a un mejor control de la misma a largo plazo. ${ }^{8}$ Esto fue en buena medida resultado del muy característico activismo judicial manifestado en las enmiendas constitucionales y la generación de leyes diversas posteriores al periodo de independencia, producto de los casos legales que en los tribunales se presentaban entre individuos frente a otros individuos o individuos frente a estados específicos de la Unión Americana.

Por su parte, el derecho continental se desarrolló como un cuerpo de reglas (leyes codificadas y decretos) con soluciones anticipadas en el papel, redactadas por legisladores, como teólogos o abogados, a veces ajenos -sobre todo en el caso de las colonias- a las problemáticas específicas, o

\footnotetext{
7 Tan ha sido una carencia importante el empleo de un sistema sólido de precedentes incluso hasta la actualidad carencia que fue fortalecida con el paso de los años por el excesivo peso que se le dio a la fuente escrita del derecho por influencia del positivismo ya en el periodo independiente- que la propuesta de fortalecerlo fue uno de los ejes principales del proyecto de iniciativa de reforma del poder judicial de la federación en México de febrero de 2020 (Carbonell, 2020). En 2009 hubo un importante avance en esta dirección con la reforma al juicio de amparo que se llevó a cabo con "el sentido de que una vez que la Suprema Corte de Justicia de la Nación haya emitido cinco sentencias sobre un mismo asunto, su resolución tendrá un alcance general y no beneficiará únicamente a los interesados”, es decir, a los que interponen el juicio de amparo. Para una explicación más detallada, véase Galindo (2021).

${ }^{8}$ A pesar de los intentos anticorrupción, con el paso de los años no se evitó la existencia de otras formas de asociación que muchas veces derivaron en prácticas corruptas que se adecuan a los marcos jurídicos anglosajones, tales como los lobbies (o grupos de cabildeo o presión cuyas acciones influyen en la administración pública para fortalecer los intereses comunes de los grupos). Estos aparecen mencionados ya en 1829. En realidad, las propias leyes estadunidenses permiten la existencia legal de estos grupos de presión (al menos desde 1876); sin embargo, que sean legales no quiere decir que sean representativos de la población estadunidense. En realidad, representan a quienes pueden pagarlos. El lobby es una gran red para traficar influencias. Tales grupos han sido por años un tema de profundo interés para la sociedad estadunidense, que considera que muchos de sus congresistas son rehenes de estas redes de interés. Incluso, los presidentes han tomado partido a favor o en contra de ellas. Para profundizar cómo actúan tales grupos, la regulación y los lazos que tienen con un sector de la población, véanse Caldevilla y Xifra (2014); Opheim (1991); Rosales (2016).
} 
carentes de experiencias previas directas sobre las cuestiones acerca de las que legislaban. ${ }^{9}$ En una real cédula de 1508, escrita por el rey Fernando el Católico para Diego de Colón, se menciona que "Porque podria ser que Yo non ser bien informado, mandé despachar cartas para las Indias; en caso de que viniese perjuicio á Nuestro servicio, Yo voz mando que veais tales cartas y las obedezcáis, y en cuanto al cumplimiento Nos lo hagáis luego saber" (Pacheco, Cárdenas, Torres, 1883, p. 189). De ello, más adelante surgiría la frase, "acátese, pero no se cumpla", haciendo referencia a que, si en los cuerpos legales se establecía algo en perjuicio de los intereses de la corona, no se cumpliera. Así, desde España se promulgaron múltiples cuerpos de leyes: reales cédulas, reales órdenes, ordenanzas y disposiciones que regulaban distintas instituciones, distintos grupos sociales, y la impartición de justicia (Cruz, 2004, p. 232). De este modo la autoridad tenía amplios poderes discrecionales en la aplicación de los múltiples y diversos cuerpos legales y trabajaba de manera cercana a los intereses locales para fortalecer el statu quo. Para los elementos que componían la elite, la ley se convirtió en una regla que se honraban rompiéndola. Para los demás individuos de la sociedad, la ley era arbitraria y ajena (Stein y Stein, 1970, p. 701).

Esto muestra el apartamiento que desde el periodo colonial ha existido entre la realidad y el derecho en las sociedades hispanoamericanas. ${ }^{10}$ Es decir, formalmente la ley debía acatarse, pero si la realidad complicaba su ejecución, entonces simplemente no se cumplía. Este aspecto del no cumplimiento de la ley se ha complejizado en las sociedades contemporáneas de la región latinoamericana en función de la percepción que tienen los individuos de la cercanía o distancia con sus gobiernos. En ese sentido, no obstante, hoy en día la ley escrita en general no considera subjetivismos en su aplicación, para algunos grupos sociales el violar la ley es "válido" en tanto no se sienten identificados con el Estado que en teoría los debe representar. Este despego de la ley ha llevado tanto en el pasado y el presente a prácticas de excepciones y privilegios desde épocas donde supuestamente estos ya no debían ser la norma (véase Root, 1994).

Además de los múltiples cuerpos legales, la sociedad en las colonias españolas estaba bajo un modelo organizacional basado en estamentos (o cuerpos con características comunes) y proponía un orden político y social asentado en estos cuerpos u organizaciones socioeconómicas, vinculadas las unas a las otras y con determinado nivel de autonomía. Todos los cuerpos estaban comprometidos a mantener la estructura funcional de una sociedad orgánica jerárquica que encabezaba el rey. Estos estamentos y multiplicidad de cuerpos legales estaban justificados ideológicamente a partir de obras de filósofos como Platón y Agustín de Hipona, uno de los más célebres teólogos de la Iglesia católica. ${ }^{11}$ Estos autores fueron leídos por quienes llevaron a la práctica este tipo

\footnotetext{
${ }^{9}$ A pesar de que los reyes eran ajenos a la realidad de la colonia eran conscientes del nivel de abusos que en ellas había, y establecieron medidas como las visitas y juicios de residencia, así como la aplicación de penas que condenaban los abusos. Sin embargo, muchas de estas medidas fracasaron. A pesar de ello, los elementos de análisis que presentan los juicios de residencia permiten observar la continuidad de prácticas de abusos y fraudes condenados en ese momento por la sociedad que hoy en día se define como corrupción.

${ }^{10}$ Sobre este tema véase Mijangos (2019, Introducción).

${ }^{11}$ Para este teólogo, la filosofía ha de estar subordinada a la teología. Tal tesis fue negativa para el desarrollo científico ya que obligaba a los pensadores a cotejar todo su pensamiento con el texto bíblico y las tradiciones católicas. Esto provocó que la separación entre ciencia y religión dada por los griegos fuese revertido en parte por las ideas de Agustín de Hipona. Para él, la ciencia debe estar subordinada a la religión, esto podemos ejemplificarlo con las visiones heliocéntricas o geocéntricas. La Biblia afirmó que el Sol giraba alrededor de la Tierra, por lo que los científicos no tuvieron más opción que adecuar sus estudios bajo este dogma religioso. El pensamiento agustino a la larga sirvió para justificar la Inquisición y la persecución de científicos (Miranda, 2015).
} 
de organización en las colonias, como los conquistadores, evangelizadores y quienes gobernaban desde España. Agustín de Hipona planteaba que la sociedad debía de encontrarse dividida por la naturaleza de los hombres.

Otros teólogos continuaron profundizando en estas posiciones, como Adalberón de Laon (998), quien criticaba que los plebeyos pudiesen obtener el derecho a formar parte del orden eclesiástico e incluso alcanzar el rango de obispos desplazando a los hijos menores de la nobleza que habían abrazado la vida clerical, por lo que ataca todo intento de cambio social del orden feudal que él idealizaba (Rucquoi, 2014, pp. 13-14).

Estas concepciones creaban una pirámide donde en la base social estaban los campesinos, en medio estaban localizados los guerreros, y en la cima el clero y los gobernantes; aunque en la realidad los cuerpos no eran estáticos como deseaban algunos teólogos. El ascenso social era posible, aunque restringido (Rucquoi, 2014, pp. 13-14). El ascenso estaba condicionado en buena medida al cuerpo en el cual naciese el vasallo. Este podía haber nacido en una república de indios ${ }^{12}$ o de españoles, legítimo o bastardo, con sangre limpia o una "mezcla vil". ${ }^{13}$ Otro elemento que empezó a cobrar fuerza en la posibilidad de ascenso social fue la riqueza generada por la nueva clase burguesa surgida sobre todo del comercio, de la cual se hablará en el siguiente apartado. El resto de los habitantes, ya fueran hijos ilegítimos o mezclas raciales, estaban prácticamente muertos civilmente en esta sociedad.

Durante el periodo de los Austrias estos conceptos fueron los que se implementaron en la Nueva España de los siglos XVI y XVII. El rey era la cabeza de este sistema que gobernaba a distancia. Como explica Jorge Traslosheros, la condición de los habitantes de Nueva España era por lo tanto de vasallaje al rey. Entonces, la corona tenía el poder de otorgar honores y privilegios a los vasallos que hiciesen servicios especialmente útiles al rey (Traslosheros, 1994, p. 47). Evidentemente, como veremos más adelante, este tema complejiza el análisis de un tema como la corrupción en redes en los términos actuales, sobre todo dentro de los cuerpos que gozaban de mayores privilegios.

Las diferentes corporaciones (cuerpos) tenían fuero, es decir, el poder de organizarse con normas internas propias, que, de no chocar con los intereses de la corona, habrían de ser aceptadas. Cada cuerpo poseía características inherentes y no todas poseían los mismos privilegios. La principal división se encontraba entre quienes resolvían sus problemas judiciales en tribunales públicos y aquellas con tribunales propios. Al mismo tiempo, estos cuerpos tenían por misión el velar por el bienestar de sus asociados y por el aumento y la conservación de sus privilegios, además de que sus funciones estaban estrechamente relacionadas con la moral cristiana, que establecía los fines que debía cumplir cada una de estas asociaciones (Rojas, 2007, p. 52). Aunque los individuos podían pertenecer a más de un cuerpo en su vida, el hecho de estar delimitados por una estructura de naturaleza limitaba la movilidad social, pero de igual forma evitaba cambios bruscos que pudiesen crear algún desequilibrio en la sociedad (Traslosheros, 1994, p. 59).

Así, la herencia de una tradición legal y religión no aptas para el avance del capitalismo, la multiplicidad de normas y ambigüedad en la aplicación de las mismas, la estructura corporativa poco flexible, la diferenciación social, y excepciones y privilegios fomentados desde los siglos del

${ }^{12}$ Este grupo se encontraba igualmente dividido entre macehuales -sometidos y explotados- y los caciques, quienes gozaban de favores, servicio de sus congéneres y nobleza. Sin embargo, sean macehuales o caciques, los indígenas se encontraban segregados del resto de la población y en una posición subordinada en la práctica a la española.

${ }^{13}$ La república de españoles era una organización social y política en la que formaban parte españoles y criollos. Tenía diferencias y divisiones marcadas, por ejemplo, se dividía entre los miembros de la nobleza, religiosos, comerciantes $\mathrm{y}$ artesanos. 
gobierno Austria en América, entre otras, probaron ser características resistentes con el paso de los años. Además, habían aportado a la creación de una sociedad jerárquica donde grupos económicos dominantes, como el de los comerciantes, aunque carentes de linaje de origen, no estaban dispuestos a ceder sus privilegios adquiridos a pesar de los cambios ideológicos que se suscitaban en el mundo del siglo xviII, ya bajo el gobierno de los reyes Borbones. Tampoco tuvieron incentivos para la innovación del aparato productivo, como sucedía en los principales centros capitalistas, por la estructura de los intereses creados. En el siguiente apartado veremos cómo el poder adquirido por algunas redes o grupos de comerciantes en las colonias españolas en América los llevó a cometer abusos y excesos para no perder concesiones y poder continuar beneficiándose, a pesar de que el contexto y las reglas estaban cambiando. La operación en redes, las costumbres arraigadas, y la resistencia al cambio son elementos que nutren parte del modus operandi que eventualmente se transformará en lo que hoy se conoce como capitalismo de amigos.

\section{LOS COMERCIANTES Y LA SEMILLA DE LA CORRUPCIÓN COLUSIVA EN LA COLONIA}

Una de las corporaciones más importantes en la colonia fue la de los mercaderes o comerciantes, en especial los de Nueva España. Eran hombres reconocidos por sus grandes fortunas que a lo largo de los años habían logrado obtener grandes beneficios pese al desprecio que recibían por parte de la vieja nobleza. De hecho, la ausencia de linajes familiares no fueron obstáculos para que los mercaderes adquirieran una presencia cada vez más fuerte en la sociedad novohispana, lo que ocasionaba que entre los mercaderes se dividiesen entre aquellos que reconocían con orgullo su pasado de pobreza, ya que consideraban que su enriquecimiento era muestra de su talento y tenacidad, o aquellos que lo callaron por considerarlo vergonzoso mientras buscaban integrarse en las filas de la nobleza mediante matrimonio o la compra de títulos (Souto, 2006, pp. 22-23).

La compra de títulos cobra auge debido a los problemas financieros de la corona desde el siglo XVII. Al principio, los titulados en América no contaron con una gran preeminencia social. Esto cambió con el tiempo ya que la titularidad nobiliaria se vinculó con el ejercicio de cargos públicos, mismos que se asignaban a partir de contar con el título y sin tomar en cuenta el mérito. El mérito en este periodo tenía una definición que emanaba de la nobleza y se basaba en la justicia distributiva. Esta justicia afirmaba que los premios y cargos debían de asignarse a la aristocracia por ser estos los mejores de la sociedad. ${ }^{14}$ Además, muchos de los puestos asignados por mérito "eran sugeridos por la Cámara de Indias, organismo que tenía la responsabilidad de proponer al rey las personas apropiadas para ocupar los cargos administrativos vacantes y despachar lo relacionado con gracias y privilegios reales" ${ }^{15}$ (Pietschmann, 1996, p. 59). En consecuencia, dentro de la asignación de posiciones por mérito quedaba fuera del aparato gubernamental la mayoría de la población. Este sistema excluía no sólo a mestizos, africanos y sus descendientes, y a la mayoría de los indígenas, sino también a las mujeres e, incluso, y dentro de los mismos españoles, eliminaba a los artesanos. Los comerciantes también estaban vetados en este esquema de mérito "por su ob-

${ }^{14}$ Esta justicia de nobles y para nobles creaba situaciones donde los castigos variaban de acuerdo con la víctima y al victimario; por ejemplo, el castigo debía de ser mayor si el crimen era por parte de alguien pobre contra un hidalgo, quien era un miembro inferior de la nobleza con linaje hereditario.

${ }^{15}$ La Cámara de Indias formaba parte del Consejo de Indias, órgano de importancia y autoridad suprema en todos los asuntos coloniales hasta comenzar el siglo XVIII. 
sesión por el dinero". Esto dejaba tan sólo a los descendientes de la nobleza europea y cristiana (y los descendientes de la nobleza indígena colaboracionista, pero incluso a ellos les estaban vetados numerosos cargos) como los únicos y legítimos poseedores del poder político. ${ }^{16}$

Las elites coloniales en distintas épocas de la colonia, pero de manera acentuada en el siglo XVII, habían buscado adueñarse de las posiciones de la burocracia judicial como una manera de obtener ganancias económicas para ellos mismos y los miembros de sus familias, y para su clientela. En este sentido, cuando la venta de puestos cobra auge aquellos que creían tener los méritos suficientes para ocupar un puesto y no lo ocupaban consideraban que la persona que lo obtuvo por medio de su compra "podía ser corrompida fácilmente al no tener un linaje de sangre limpio, lo que podía hacer caer en distintas tentaciones" (Rosenmüller, 2019, p. 2). Además de que muchos de los que habían recibo su puesto por medio del mérito se veían afectados debido a que ya no podían acceder a un puesto más alto por medio del ascenso si estos puestos eran comprados por alguien más, y por otro lado los que compraban el puesto en su lugar de origen podían tener una influencia directa en asuntos relacionados con la administración y la justicia (Burkholder y Chandler, 1984, p. 18), ocasionando que esto "fuera para muchos de los miembros de la nobleza una violación de la justicia y por ende, corrupción e incluso tiranía” (Rosenmüller, 2016, p. 66). Así fue la principal forma como se entendía la corrupción en el periodo colonial.

Aunque para algunos el hecho de que los comerciantes compraran títulos y puestos fuera "corrupción”, el poder de los comerciantes y de sus redes crecía y se veía reflejado en los principales ámbitos de la vida en Nueva España. Debido a que se valían de diversas estrategias, como explica Guillermina del Valle Pavón (2012):

habilitaban a los mineros e invertían en la producción argentífera; dominaban el tráfico de los bienes agropecuarios de mayor valor y demanda; utilizaban medios de pagos alternativos; solicitaban crédito a mediano y largo plazos a las corporaciones religiosas; recibían préstamos de sus colegas y dinero a réditos de sus allegados. La disposición del circulante les permitía adquirir bienes locales y del exterior en los términos más ventajosos, efectuar ventas con pagos diferidos y otorgar crédito en dinero a corto plazo. A través de estas prácticas podían sostener complejas redes de agentes y socios en los principales núcleos comerciales del virreinato, de otras colonias hispanoamericanas y de la metrópoli (pp. 8-9).

Así, el poder que tenían los comerciantes había crecido considerablemente gracias a su capacidad de comprar cargos: "A principios del siglo xvir en el Cabildo de la Ciudad de México el $75 \%$ del regimiento estaba compuesto de mercaderes" (Souto, 2006, p. 22). Además, los comerciantes regulaban sus actividades comerciales por medio de poderosos consulados, como el de la misma ciudad de México. Aquí buscaban una solución rápida de los pleitos, y luchaban por mantener y aumentar privilegios. En los consulados también se impusieron las condiciones para ocupar cargos de jueces consulares y así regular su trabajo, buscando la idoneidad en función de los intereses de los comerciantes. A esto se refiere Souto Mantecón (1990): "Los que obtuviesen los cargos debían ser personas prácticas e inteligentes en materia de comercio" (pp. 243-244).

${ }^{16}$ Por otra parte, el mérito y la vida recta bajo los parámetros católicos eran tan importantes como la "recomendación”: la participación del recomendado en redes clientelares. 
Gracias a la compra de puestos muchos comerciantes y personas relacionadas con ellos llegaron a diferentes instituciones, algunas muy importantes, como las Audiencias, encargadas de gobernar la justicia en las colonias españolas. En las Audiencias, la principal característica jurídica era "la imprecisión misma de la delimitación de las funciones del más alto tribunal colonial, al mismo tiempo legislativas, ejecutivas, judiciales y fiscales, esto hacía que sus miembros se comportaran habitualmente como magistrados inmunes a cualquier crítica y a todo control" (Colmenares, 1979, p. 204). Los miembros de las Reales Audiencias, que eran los máximos tribunales coloniales, recibían continuamente acusaciones relacionadas con conflictos de interés y la mezcla de actividades públicas y privadas. Una forma común de ganancia de los funcionarios judiciales era mediante el cobro de cuotas sobre la resolución de pleitos entre particulares. Muchos de los cuales ellos mismos fomentaban para obtener un beneficio del conflicto. Así la compra de un puesto "demuestra que no se trataba del salario por percibir o el valor monetario que se pagaba por él lo que conllevaba su compra, sino el beneficio que se podía obtener con un cargo de esta naturaleza" (Miranda y Zabala, 2016, p, 179).

Por otra parte, la venta de plazas a individuos cercanos a los grupos de comerciantes también tuvo un papel clave en amortiguar las ineficiencias del sistema legal poco propicio para el desarrollo de una economía que ya dejaba ver el avance de los procesos económicos hacia el capitalismo. ${ }^{17}$ Existen ejemplos que llaman la atención sobre cómo la compra de posiciones en ocasiones jugó en favor de agilizar los procesos económicos en un entorno institucional débil, como el que caracterizó a las colonias españolas como consecuencia en parte de la ambigüedad legal. Abordaremos un ejemplo en la siguiente sesión.

Para finales del siglo XviI y principios del XviII, ya en el periodo Borbón, el concepto de corrupción toma otro giro más en la dirección hacia lo que hoy se entiende por corrupción. El nuevo concepto se ve influenciado por las ideas ilustradas ${ }^{18}$ y en beneficio ya no de la vieja nobleza sino de la burguesía, la clase social que había ido formando su riqueza por medio del trabajo, como los comerciantes, mineros y hacendados, que venía a disputar el viejo dominio de los hidalgos. Ya con la casa Borbón en el poder en España se inicia una serie de reformas; una de ellas sería que la Cámara de Indias -encargada, como se mencionó anteriormente, de sugerir al rey quién debía ocupar puestos- ya no se tomaría en cuenta para estas sugerencias (Pietschmann, 1996, p. 60). Entonces, los méritos de la nobleza ya no son el elemento que define la idea de corrupción en el contexto de cambios que implementarían los borbones durante el siglo xviII, con las cuales se buscó un nuevo orden administrativo mucho más racional en el que los intereses económicos de la corona estaban por encima de todo. De este escenario deriva una definición ilustrada de justicia y corrupción, en un contexto en donde "surgía un intercambio más racional a través del mercado y la burocracia y

${ }^{17}$ Como herencia de esta práctica colonial, la mayoría de los países latinoamericanos tras su independencia y en las primeras décadas del siglo xx solucionaron con la formación de redes sociales las ineficiencias de un sistema legal débil o poco adecuado para el desarrollo capitalista. Stephen Haber considera que fue precisamente la debilidad de las instituciones formales el detonante de la formación de las redes y el capitalismo de amigos, el cual, de acuerdo con Galindo (2021), más avanzado el siglo xx se transformaría en algo más pernicioso y enfocado solamente en satisfacer los intereses económicos de las redes de empresarios y no en amortiguar las debilidades institucionales. Véase Galindo (2021).

18 Aunque las ideas ilustradas derivarían en racionalizar todos los aspectos de la vida pública y privada, cuando se empiezan a desarrollar estas ideas a mediados del siglo xviII, el rey es el que tiene el poder absoluto, la base del pensamiento se vuelve la razón, y en ella surge la idea de un progreso con el que se busca el beneficio para el rey (Pagden, 1997). 
afloró el ideal burgués de la utilidad, de manera que el origen social como argumento contra la corrupción perdió validez ante la educación formal, la experiencia y el rendimiento" (Rosenmüller, 2016, p. 74).

Según Rosenmüller, en el siglo xviII se observa a la corrupción como la violación de las leyes, a la que él llama como corrupción performativa. En esta definición, el pertenecer a la aristocracia y al alto clero ya no son de importancia para la ocupación de un puesto, y la pureza de sangre ya no implica que no se cometieran actos corruptos: "La corrupción ahora es vista como la violación de las leyes de Castilla e Indias gobernando la actuación en el cargo público" (Rosenmüller, 2016, p. 79). Sin embargo, Juan Carlos de Orellana Sánchez (2019, p. 80), por medio de un estudio que hace de la obra de Juan de Solórzano (1647), afirma que a partir de la segunda mitad del siglo Xvir la noción de que la corrupción suponía violar las leyes de la corona ya era fuerte y no desde finales del siglo xvir como lo afirma Rosenmüller. Francisco Andújar-Castillo también sostiene que desde la segunda mitad del siglo Xvi la palabra aparece con la misma significación que le damos hoy e integra abusos, excesos, cohechos, sobornos, malversaciones, dádivas, granjerías, tratos y contratos, tratos y negocios, baraterías, manejos, malos procedimientos y mala administración de justicia. Casi siempre todas esas prácticas, según Andújar-Castillo (2019, p. 320), eran perseguidas por la justicia.

Observamos entonces que en el periodo colonial la forma de ver la corrupción fue cambiando con el paso de los años. Así, en el siglo XviII la corrupción sería vista por jueces y corregidores del gobierno borbón como el quebrantamiento de las leyes de Castilla y de Indias y ante la Ilustración se empezaba a cuestionar el pluralismo judicial, basado en colecciones romanas, fuentes teológicas e interpretaciones medievales (Rosenmüller, 2016, p. 75). Bajo este contexto, grupos de burgueses prósperos generaron alianzas con protagonistas del poder real y, en conjunto, hacen a un lado y se desvían de las normas legales en diferentes circunstancias. Estas alianzas son el embrión de las prácticas posteriores de formación de redes entre empresarios y políticos que derivaría en lo que hoy se conoce como capitalismo de amigos o, para efectos prácticos, corrupción colusiva, en la que elementos del sector público y privado se coluden y, actuando en red, se alejan o hacen mal uso de las leyes en busca de sus propios beneficios, práctica que persiste hasta nuestros días. ${ }^{19}$

En el siguiente apartado se intentará explicar a partir de la violación de las leyes cómo diferentes grupos de personas violentaron y manejaron las normas e incluso ocasionaron que fueran suspendidas para su beneficio en un contexto colonial de cambios y reformas. Aunque los casos que se analizan más adelante no fueron llamados corrupción como tal, sí fueron casos que resonaron entre la población, al ser considerados como abusos y excesos de quienes gobernaban. Posteriormente, acciones de esta naturaleza serían incluidas dentro del marco de la corrupción.

\section{AlgunOs CASOS DE PRECAPITALISMO DE AMIGOS EN LA COLONIA ${ }^{20}$}

El siglo XVIII es conocido, en la historiografía a partir de la década de 1960, como el periodo de las reformas borbónicas, debido a que en ese periodo la casa Borbón estaba al frente de la corona española e implementó una serie de cambios administrativos y políticos (Sánchez, 2016). Sin embargo, fue hacia la mitad del siglo xviII cuando los cambios tomaron mayor fuerza; no

${ }^{19}$ Para una explicación más detallada sobre este tipo de relaciones en la actualidad véase Galindo (2021).

${ }^{20}$ Por precapitalismo de amigos nos referimos a todas aquellas prácticas que se asemejan al capitalismo de amigos actual pero que se dieron en un periodo en donde todavía no se puede hablar formalmente de capitalismo en las colonias españolas en América, sino de un proceso inicial de implementación del mismo. 
obstante, muchos de los filósofos y pensadores españoles de los siglos XVI y XVII ya expresaban la necesidad de realizar modificaciones en diversas áreas económicas. Por ejemplo, Sancho de Moncada y Miguel Álvarez Ossorio consideraban qué reformas en agricultura e impuestos serían benéficos para los ingresos de la corona (Pietschmann, 1996, p. 22).

Con la llegada de rey Carlos III de Borbón se priorizó el tema económico. En términos generales, se impulsó una administración más centralizada, la unificación de diferentes cuerpos legales, así como una división territorial mejor definida. También continuaron las visitas desde la metrópoli a las colonias para fiscalizar el avance de los temas y las problemáticas particulares. Esta nueva administración se enfrentó a diversos intereses de los habitantes de las colonias, sobre todo a los de aquellas redes de comerciantes y los lazos que había con los trabajadores de la corona. ${ }^{21}$ Estas redes se habían fortalecido con el transcurso de los años, lo cual había consolidado relaciones de amistad en la que la amistad suponía confianza, reciprocidad e intercambio de servicios (Imízcoz, 1996, p. 36). Pero, ¿cómo actuaban las redes sociales de comerciantes en un contexto de transición al capitalismo y qué herencia dejaron en las prácticas económicas de la región?

En este apartado desarrollaremos cuatro casos que se presentaron en el periodo colonial, ${ }^{22}$ comenzando con el que expone Luis E. Fajardo, quien analiza un caso que nos presenta un antecedente directo de la operación de redes y grupos cerrados para compensar las debilidades institucionales existentes; situación que también caracterizó a la América Latina independiente, sobre todo de finales del siglo xix. Es decir, el autor desarrolla un caso de los años tardíos de la colonia que se asemeja al capitalismo de amigos temprano, ya definido como tal, que se presentó frecuentemente en los países latinoamericanos hacia los años que en la historiografía de la historia económica latinoamericana se conocen como de "crecimiento impulsado por las exportaciones". El caso analizado por Fajardo es el de un grupo de comerciantes españoles "que compró en 1795 el derecho a operar el Consulado de Cartagena, principal tribunal encargado de resolver disputas en la plaza; es decir, los comerciantes más acaudalados compraron al Rey el derecho de formar un tribunal cuyos miembros eran escogidos entre ellos mismos" (McFarlane, 1997, pp. 276-277). Así, la defensa de sus intereses particulares y solución de las disputas fue más importante para ellos en términos económicos que la cantidad pagada al rey (Miranda y Zabala, 2016, p. 180). "El tribunal comercial más importante de la Colonia se convirtió así en una fraternidad cerrada al resto de la sociedad neogranadina y en un mecanismo" que los poderosos "capturaron para defender sus intereses privados"; "una institución que normalmente debería de tener un carácter público" (Fajardo, 2002, pp. 27-28).

Lo interesante de este caso es que los comerciantes ultramarinos de Cartagena son el grupo de comerciantes que en aquel momento más vínculos tenía con las rutas del comercio global en el sur de la América española. Las peculiaridades de este comercio globalizado marítimo exigían un sistema legal confiable y unificado (no ambiguo), que coincidió en tiempo con los esfuerzos de los borbones para generarlo, pero con el que aún no se contaba en ese momento en los virreinatos. Es por ello que los comerciantes de Cartagena recurrieron a esta compra que limitó las funciones del Consulado a un grupo específico, en el cual los matrimonios y lazos de sangre reforzaron la

${ }^{21}$ Cabe aclarar que el fracaso del reformismo borbónico no puede ser entendido sólo por el accionar de los actores americanos. Es un tema complejo que requiere del análisis de diversos elementos fuera de los objetivos de este texto.

${ }^{22}$ Los cuatro casos que se desarrollan en este apartado se eligieron entre la historiografía de las últimas décadas del siglo xx y lo que va del xxi, en función de la explicación que con rigor científico realizan sobre las redes de comerciantes y miembros del orden colonial y su oposición a diversos cambios defendiendo sus intereses y prácticas que se asemejan o pudieron ser el inicio del capitalismo de amigos actual. 
identidad de los intereses económicos. Con esto garantizaron la creación de derechos de propiedad intangibles que les permitieron operar. Además, destaca el asunto de que otros comerciantes de zonas aledañas también pidieron a la corona el derecho a organizar nuevos consulados, pero este les fue negado, lo que demuestra que diversas elites del virreinato buscaron y obtuvieron un sistema judicial "privatizado", mediante el cual lograron eludir la ineficiencia dominante en el resto de los tribunales de la Nueva Granada. Entonces, en el caso de España, la justicia se ofreció "como una valiosa prerrogativa subastada por la Corona a sus favoritos" (Fajardo, 2002, p. 28).

Esta característica continuó a lo largo de todo el siglo xIx y la primera mitad del xx en la mayoría de los países latinoamericanos. La mayoría de los nuevos países independientes continuaron operando en un entorno de instituciones formales débiles en donde los derechos de propiedad eran débiles y no existía una certidumbre en el uso de instrumentos legales como los contratos. En ese sentido, las redes conjuntas formadas por elementos de los sectores público y privado para hacer negocios (capitalismo de amigos) jugaron a favor de dar fuerza y certidumbre a las operaciones económicas. El problema surge en el sentido de que no todos los actores económicos tuvieron acceso a formar parte de estas redes ${ }^{23}$ y a los privilegios que eso conlleva. Esto, a la larga sesga los incentivos y las decisiones económicas, alejando a la economía de un modelo competitivo ideal.

Por otra parte, como observamos anteriormente, el siglo XvIII tuvo unas características particulares por la llegada de los borbones al poder. Bajo este contexto, existen otras historias específicas de resistencias a las reformas ilustradas del siglo xviII dentro del imperio español que merecen la pena retomarse para hacer algunas conclusiones en relación con el peso de la mezcla de los intereses económicos privados y públicos en detrimento del avance de las instituciones formales, lo que se heredaría a las prácticas de los países latinoamericanos independientes. Cabe destacarse que la característica más perniciosa del capitalismo de amigos, sobre todo de la segunda mitad del siglo xx hasta la actualidad, tiene que ver con la paradoja del capitalismo de amigos en la América Latina independiente en el tránsito de la debilidad al fortalecimiento institucional: si durante gran parte del siglo XIX la existencia del capitalismo de amigos (redes de intereses compuestas por individuos de los sectores público y privado) fue un elemento que permitió que las economías funcionaran en un entorno de debilidad institucional -como se mostró también para el periodo colonial tardío en algunos elementos del ejemplo de Fajardo- con el paso de los años es este mismo capitalismo de amigos lo que ha mantenido débiles a las instituciones.

Para ejemplificar los argumentos planteados, se analizarán: el debate sobre el repartimiento de mercancías, tomando parte del estudio realizado por Stanley Stein ${ }^{24}$ realizado en 1981 y un caso de corrupción colonial en Perú, de Alfonso Quiroz, publicado en su libro de $2013 .{ }^{25}$ Ambos

${ }^{23}$ Un ejemplo de la operación de redes sociales y mercantiles durante el proceso de independencia y los primeros años del México independiente es analizado por Ernest Sánchez Santiró en un trabajo publicado en 2007. En él demuestra que las redes sociales y mercantiles también dieron estabilidad en el contexto de incertidumbre que se vivía en el país, lo que se asemeja a las características del capitalismo de amigos temprano explicado anteriormente.

${ }^{24}$ El trabajo de Stanley Stein (1982) sobre repartimiento de mercancías causó numerosos debates debido a los métodos y fuentes utilizadas por el autor. Por ejemplo, Barbier y Burkholder (1982) niegan que el ataque al repartimiento constituya una reforma en sí y que existieran vínculos entre la burocracia y la sociedad en este contexto debido a la falta de evidencia y a las generalizaciones que realiza Stein. Sin embargo, las prácticas que narra Stein tienen que ver con un tema de resistencia a perder privilegios que continúa vigente, así como las afectaciones económicas. Para revisar más a detalle el debate, véase Stein (1982).

${ }^{25}$ El estudio de Alfonso Quiroz (1956-2013), que presenta una historia detallada de la corrupción en Perú desde la época colonial hasta el siglo xx, nos explica los costos económicos que esta ha tenido en ese país, con cálculos claros de las consecuencias de la corrupción sistémica. 
profesores fallecieron recientemente y fueron sin duda destacados e innovadores estudiosos de las redes de intereses en el periodo colonial, además de añadir aportaciones sustantivas al debate específico del peso de estas redes en fracasos reconocidos de las reformas borbónicas, mismos que se asemejan a muchos fracasos de reformas legales contemporáneas por poner en peligro los intereses de redes de poderosos. Es así como los intentos de fortalecimiento institucional muchas veces claudican ante estos intereses en la región latinoamericana.

Quiroz explica cómo los funcionarios reformistas de la época borbónica se enfrentaron, sobre todo a partir de la década de 1750, a poderosos intereses profundamente incrustados en la sociedad virreinal que ofrecían resistencias y dificultades extraordinarias. Él analiza casos específicos de Perú. Por ejemplo, el del reformista Antonio de Ulloa, que entre 1758 y 1764 fue el encargado de ordenar la administración local del poblado minero de Huancavelica, mismo que contaba con la importante mina de mercurio de Santa Bárbara, única fuente de mercurio en el territorio americano, utilizado para la refinación de la plata. Sin embargo, los esfuerzos reformistas de Ulloa fueron frustrados de acuerdo con Quiroz.

Pero, ¿̇cuáles fueron los aspectos sistémicos más profundos de la oposición a los esfuerzos reformistas de Ulloa en Huancavelica? El entendimiento entre las autoridades políticas y los intereses creados vinculados a la minería de plata y su comercio, financiamiento, impuestos reales que generaba, y el contrabando al que daba lugar desde al menos los inicios del siglo XviII, generando fuertes pérdidas para la corona. Estas conexiones favorecieron las ganancias privadas en menoscabo de la producción y la honesta administración. Estos intereses se hallaban controlados desde la cima por autoridades políticas que buscaban ganancias privadas a costa del bien público, desde los virreyes, que se rodeaban inicialmente de miembros cercanos que viajaban con ellos desde España. La red virreinal se expandía luego para atraer a intereses locales ávidos de galantear al nuevo virrey. Este patrón se repitió en los gobiernos de sucesivos virreyes desde los primeros tiempos de la colonia.

Evidencias detalladas derivadas de análisis proporcionados por reformadores coloniales y fuentes judiciales, administrativas y cuantitativas ratifican la principal afirmación sobre que lo que actualmente se conoce como capitalismo de amigos, producto en este caso de las redes de intereses entre gobernantes y productores-comerciantes, tuvo un papel central en el sistema colonial y es el fundamento de la corrupción colusiva. Incluso, a pesar de la aplicación de las reformas muchos de sus beneficios en vez de remitirse a la península, se redistribuyeron en un alto porcentaje en el virreinato, favoreciendo a grupos sociales muy concretos demostrando el fracaso de las reformas en beneficio de la corona contrario a lo que se ha creído de acuerdo con la consulta de fuentes oficiales (Pérez, 1991, p. 231), así, la búsqueda de obtener más riqueza y la corrupción profundamente enraizada venció. Las reformas implementadas no lograron alcanzar las metas de largo plazo necesarias para erradicar la ineficiencia administrativa colonial y limitar la corrupción.

La oposición a las reformas implementadas por los borbones se mostró de diversas otras formas y esto nos lo explica a detalle el profesor Stein para el caso de los corregidores y alcaldes mayores, quienes, según él, eran de los distribuidores más importantes de la producción de los comerciantes más ricos, generalmente peninsulares, o de importadores de gran escala. El papel combinado de juez y comerciante que tenían los corregidores y alcaldes mayores condujo a una extraordinaria licencia y especulación en colusión con los grandes comerciantes o importadores. Los alcaldes mayores actuaban no tanto como jueces sino como comerciantes, dotados de un privilegio exclusivo y el poder de hacerlo cumplir para monopolizar el comercio en su zona y extraer beneficios de ella: y, cuando pasaban a desempeñar su puesto, cometían una serie de excesos, extorsiones y abusos de 
toda índole en contra de los indios. Esto les permitía recuperarse económicamente en corto tiempo sacando provecho del puesto recientemente obtenido. Como resultado, se dieron una serie de quejas y levantamientos por parte de los indios (Andújar-Castillo, 2019, p. 321).

Así, "después de mucho debate, y en nombre de la libre empresa, los repartimientos de mercancías $^{26}$ fueron prohibidos en algunos virreinatos americanos en la década de 1780 [...] Se inició una intensa lucha política, caracterizada por la continua rivalidad entre aquellos asociados en monopolios comerciales tradicionales y los que imaginaban un sistema más abierto" (Stein, 1981, p. 13). Sin embargo "ni las ordenanzas, ni los controles oficiales ni los hombres del rey ${ }^{27}$ pudieron destruir el sistema, debido a los recursos de evasión que se presentaron. Se palpaba así una resistencia en defensa de los intereses creados en defensa de las practicas" (Pastor, 2002, pp. 254-255). Al conflicto se sumó la cuestión sobre si pagar salarios a los administradores locales (subdelegados) o permitirles continuar con un repartimiento limitado. Así, el argumento de Stein es que para Gálvez el manejo del monopolio y el abuso debían de reducirse o eliminarse y esto trajo divisiones entre los grupos de interés. Para Stein (1981), "no remodelar el sistema de intendencia y no asignar salarios a los administradores locales no fueron ni el primer ni el último ejemplo de fallas y una reforma largamente bloqueada en el imperio español del siglo Xvin" (p. 27).

Después de años de discusión, un Ministerio de Hacienda trató de resolver el problema arrebatando el tema de la creación de un código general para las intendencias a un reacio Consejo de Indias. La ordenanza resultante de 1803 volvió a prohibir el repartimiento y estableció que los subdelegados recibieran salarios. Sin embargo, estas disposiciones no se aplicaron como se esperaba. Debajo de la vacilación, la ambivalencia o la impotencia de los burócratas reformistas, así como la tenacidad de los partidarios del sistema de repartimiento, estaba el poder de la elite comercial de Nueva España, con sus redes extendidas en España y América. Los vínculos entre burócratas gubernamentales y los intereses económicos coloniales en parte bloquearon el desarrollo económico de la península. La explotación de los enclaves del repartimiento ejemplifica cómo las redes de intereses compitieron y defendieron el acceso limitado a los consumidores y productores indios.

El fracaso en remodelar el sistema de intendencias y el fracaso de los esfuerzos reformistas de Ulloa en Perú no son ni los primeros ni los últimos ejemplos de reformas bloqueadas por los intereses de los grupos de poder en el imperio español del siglo XVIII. Como lo muestra el siguiente ejemplo de Guillermina del Valle, los grupos en contra de las reformas llegaron incluso a organizar un golpe de Estado en contra de un virrey en un periodo muy delicado debido a la ocupación francesa de la península ibérica. Fue en Nueva España en 1808 cuando el virrey Iturrigaray aplicó la Ley de Consolidación de los Vales Reales. La aplicación generó grandes descontentos principalmente entre aquellos que debían grandes capitales. Entre ellos se encontraban los principales miembros del Consulado de Comercio de la Ciudad de México, Consulado que había obtenido gran poder. Incluso "se formaron los consulados de Veracruz y Guadalajara en 1759 para reducir

${ }^{26}$ El repartimiento de mercancías fue un fenómeno económico que se manifestó de diversas formas en las colonias hispanoamericanas entre los siglos XVI y XVIII. En este participaban comerciantes, autoridades locales e indígenas, y fundamentalmente consistía en que se le daba al indio de manera anticipada un pago a cambio de algún producto o cosecha de alta demanda en el mercado, dejando al indígena sin la posibilidad de comerciar de manera libre y sin recibir el precio justo por su producto. Otra forma común de repartimiento de mercancías consistió en obligar a los indios a adquirir una serie de productos que no necesariamente requerían, endeudándolos, y obligándolos a pagar por ellos con efectivo, trabajo y/o tierras. Esta fue una forma recurrente de explotación hacia los pueblos originarios.

27 Debido a la compra y la gran participación de los originarios de las colonias en los puestos se llevó una medida en la que la nueva burocracia era enviada desde España con la finalidad de romper los lazos existentes entre los ministros y la sociedad colonial (Burkholder y Chandler, 1984, p. 175). 
el poder que había obtenido" (Valle, 2007, p. 164). El grupo, después de no haber sido escuchado por el virrey, fue liderado por el comerciante Gabriel de Yermo, junto con los miembros del Consulado.

Había gozado de un trato privilegiado por parte de los virreyes novohispanos, en especial de los que habían gobernado a partir de la década de 1780, cuando se requirió de su apoyo financiero para sostener las guerras contra las potencias europeas. Iturrigaray pretendió imponer al Consulado su voluntad, sin darse cuenta que se enfrentaba a un poderoso cuerpo que sabía cómo acogerse al amparo de las autoridades de la metrópoli para limitar las facultades del virrey (Valle, 2012, p. 213).

La acción del virrey ocasionó que se diera el atentado contra él y que fuera quitado de su puesto, como una reacción por afectar los intereses económicos de los comerciantes, además, más adelante Yermo "logró establecer un poder sobre el nuevo virrey y lograron que suspendieran la Consolidación, que se cancelaran las anualidades y el subsidio eclesiástico, así como el gravamen sobre las capellanías, lo que muestra la alianza de los golpistas con el Clero" (Valle, 2012, p. 214). Esto nos muestra también la fuerte cercanía que lograron establecer los comerciantes con los miembros del poder, incluso de limitar y cambiar las leyes para el beneficio propio de los comerciantes y sus aliados, práctica que se asemeja al capitalismo de amigos actual.

Aunque todas las prácticas, excesos y abusos explicados en este apartado no fueron llamados corrupción como tal en los términos actuales, sí fueron mal vistos por la sociedad en general -y más en un contexto ideológico cambiante que empezaba a considerar la igualdad social y la homogenización de las leyes al menos en el papel- lo que eventualmente llevaría a su inclusión en las leyes. Estas, sin embargo, continuaron aplicándose de manera excepcional con el paso de los años. De hecho, como ha demostrado Luis Villoro (1994), la independencia en México la terminaron cerrando individuos pertenecientes a grupos privilegiados de Nueva España, que no estaban dispuestos a perder estos privilegios ante el contexto ideológico cambiante en Europa. Aunque estos individuos compartieron el poder con otros emanados de primeros y más populares movimientos independentistas a lo largo del siglo xIx, replicaron prácticas de excepcionalismo y privilegios que han probado ser duraderas. Las relaciones entre los miembros de los cuerpos políticos y comerciantes desde tiempos coloniales generaron que la riqueza se concentrara en pocos, creándose así grandes monopolios y el aumento de privilegios, dejando fuera de los beneficios a la mayoría de los habitantes de Nueva España y del México independiente.

\section{Conclusiones}

La mayoría de las formas patrimoniales, de patronazgo y clientelares que tuvieron su origen en América Latina en prácticas coloniales han favorecido los intereses particulares de las camarillas de los poderosos, lo que se ha mantenido a lo largo de los años, incluso después de la propagación de nuevos contextos ideológicos que enfatizan la racionalidad económica y las ideas de igualdad y libertad. A las prácticas conjuntas entre los gobiernos que emergieron posteriormente a los procesos de independencia latinoamericanos y el sector privado, heredadas de estas formas coloniales, se les ha dado el nombre de capitalismo de amigos. Hoy en día, en mayor o menor grado, en todas las economías de los países existe capitalismo de amigos, es decir, redes entre políticos y empresarios que operan a favor de sus intereses particulares. 
Stephen Haber planteó un modelo de integración política vertical tratando de teorizar el capitalismo de amigos en América Latina de finales del siglo xix y principios del xx. Para Haber, los acuerdos entre los sectores político y empresarial garantizaban la protección por parte del gobierno de los derechos de propiedad de los empresarios y otras políticas favorables a sus intereses. A cambio, los empresarios garantizaban un ingreso a los funcionarios del gobierno, además de impuestos para el funcionamiento del aparato del Estado. Esto se parece al caso estudiado en el artículo sobre los comerciantes de Cartagena en la colonia. Es decir, los comerciantes de Cartagena garantizaron, con la compra privilegiada que el rey les ofreció a finales del siglo XviII del derecho a operar el Consulado de Cartagena, la creación de derechos de propiedad intangibles que les permitieron manejar sus prácticas comerciales efectivamente en un entorno de debilidad institucional. Sin embargo, no todos los individuos de la sociedad tuvieron acceso a estas prerrogativas, lo que generó sesgos en las prácticas económicas. Además, la mezcla de los intereses de la burguesía con algunos gobernantes en el periodo colonial tardío también jugó en contra de las tan necesarias reformas políticas y administrativas influidas por las ideas ilustradas que se planteaban. Estas fueron limitadas por poderosos intereses creados profundamente incrustados en la sociedad virreinal que ofrecían resistencias y dificultades extraordinarias. Estas segundas características se parecen más al capitalismo de amigos actual, que ha impedido el fortalecimiento y las reformas a las instituciones formales.

Es decir, si en algunos casos, las prácticas coloniales heredadas a América Latina llevaron a la generación de redes de políticos y empresarios que en momentos de incertidumbre económica y política durante parte del siglo xIX y principios del xx apoyaron al fortalecimiento del Estado, la reconstrucción de la economía y la generación de inversión privada; con el paso del tiempo, a lo largo del resto del siglo xx y hasta la actualidad, ya no fue la necesidad lo que mantuvo esta relación entre políticos y empresarios, sino más la pura conveniencia mutua de la ganancia económica, generando así que se hayan conservado débiles instituciones formales fundamentales, lo cual resulta paradójico.

Por otra parte, con el afán de evitar el relativismo histórico en la definición del concepto de corrupción, es importante mencionar que aunque haya existido un cambio en el contexto histórico entre el periodo colonial, el posindependentista y el actual, y el concepto de corrupción haya cambiado de manera sustantiva a lo largo de los años, la idea que la sociedad tenía sobre el bien y el mal de diversas prácticas desde la colonia -que bien hoy podrían llamarse corrupción- se ha mantenido más o menos estable, lo que tiene que ver en parte con que en Hispanoamérica un componente sustantivo de los cuerpos legales emana de la moral cristiana desde el temprano periodo colonial, con los mandamientos de la ley de Dios y las diversas interpretaciones cristianas encabezando el proceso de construcción legal. Entonces, aunque la corrupción actual no es corrupción colonial de acuerdo con la definición de aquel momento, existieron otros términos contemporáneos como abuso y fraude que bien pueden caer en la clasificación actual de la corrupción, lo que incluso llevó a que se practicaran los juicios de residencia en la colonia. Además, en el mismo periodo colonial la influencia de las ideas de la Ilustración fue acercando más el concepto de corrupción a la definición actual, sobre todo a lo largo del primer siglo de gobierno Borbón en España.

El aparato legal también ha evolucionado y se ha desarrollado de manera sustantiva a lo largo de los siglos. Este pasó de un pluralismo jurídico ambiguo a la homogenización de los cuerpos legales, aunque con una carencia importante en relación con el derecho anglosajón: el uso adecuado de la jurisprudencia para acercar de manera más directa y práctica el aparato legal a la realidad. En la actualidad las leyes contemplan las prácticas corruptas -que de manera general se dividen en 
extorsivas y colusivas-, que se empezaban a presentar desde tiempos coloniales, y la capacidad del Estado para ejercer medidas contra la corrupción. Así como en épocas anteriores el aparato legal era más limitado y tenía menor alcance en los espacios de un amplio y poco comunicado territorio, al día de hoy deberían de existir todos los elementos para hacer valer la ley, pero las costumbres arraigadas han generado que en muchas ocasiones se utilicen en función de los intereses de los que tienen el control para hacer ejercer la ley, partiendo de los políticos de alto rango.

Finalmente, es importante mencionar que las diferencias en algunas prácticas entre los países han mostrado ser fundamentales para los avances y retrocesos institucionales. El progreso de países más desarrollados en cuanto al fortalecimiento institucional está en función no sólo de algunos de los elementos desarrollados en este artículo, como las ideas de pensadores específicos, y la evolución particular de las fuentes legales y aplicación de las leyes, entre otros, sino también de aspectos más subjetivos que tienen que ver con el equilibrio entre la ambición personal y búsqueda del bien común. También se puede afirmar que, aunque la corrupción ha disminuido con el tiempo en algunas naciones, no ha sido eliminada en países desarrollados, en donde continúa siendo un problema recurrente. Sin embargo, los niveles de corrupción en muchos de estos países, aunque resistentes, no han probado estar por encima del avance -a veces lento y con retrocesos, pero continuo- de la construcción de instituciones formales sólidas que permiten ejercer procesos de control incluso en áreas en donde los intereses de los ricos pueden ser severamente afectados, como con la legislación antimonopólica.

\section{LISTA DE REFERENCIAS}

Adelman, J. (ed.). (1999). Colonial legacies: The problem of persistence in Latin American history. Nueva York: Routledge.

Andrien, K. (1984). Corruption, inefficiency, and imperial decline in the seventeenth-century viceroyalty of Peru. The Americas, 41(1), 1-20.

Andújar-Castillo, F. (2019). Controlar sin reformar: La corrupción de los virreyes de Indias en el siglo XviI. Memoria y Civilización, 22, 317-342. DoI: 10.15581/001.22.020

Andújar-Castillo, F. y Ponce, P. (2018). Introducción. En F. Andújar-Castillo y P. Ponce (eds.), Debates sobre la corrupción en el mundo ibérico, siglos XVI-XVIII (pp. 11-14). Alicante: Biblioteca Virtual Miguel de Cervantes. Recuperado de http://www.cervantesvirtual.com/obra/debatessobre-la-corrupcion-en-el-mundo-iberico-siglos-xvi-xviii-928763/

Annino von Dusek, A., Castro, L. y Guerra, F.-X. (1994). Iberoamérica de los imperios a las naciones. España: Ibercaja.

Barbier, J. A. y Burkholder, M.-A. (1982). Critique of Stanley J. Stein's "Bureaucracy and Business in the Spanish Empire, 1759-1804: Failure of a Bourbon Reform in Mexico and Peru". Hispanic American Historical Review, 62(3), 460-468. DoI: 10.1215/00182168-62.3.460

Berman, H. (2001). La formación de la tradición jurídica de Occidente. México: Fondo de Cultura Económica.

Borchart de Moreno, Ch. R. (1984). Los mercaderes y el capitalismo en la Ciudad de México: 17591778. México: Fondo de Cultura Económica.

Burkholder, M. A. y Chandler, D. S. (1984). De la impotencia a la autoridad: La Corona Española y las Audiencias en América, 1687-1808. México: Fondo de Cultura Económica.

Caldevilla, D. y Xifra, J. (2014). Historia de los Lobbies: Una forma de escribir la historia. Historia y Comunicación Social, 18(0), 879-892. DoI: 10.5209/rev_HICS.2013.v18.44371 
Carbonell, M. (2020). Reformar al poder judicial: Cambios a fondo. México: Centro de Estudios Carbonell. Recuperado de https://www.youtube.com/watch?v=TIRlzDD4IyY

Carrasco, A. (2018). El caso del gobernador Borrás y sus cómplices: Contrabando y abusos fiscales en el puerto de Alicante a finales del siglo xviI. En F. Andújar-Castillo y P. Ponce (eds.), Debates sobre la corrupción en el mundo ibérico, siglos XVI-XVIII (pp. 585-597). Alicante: Biblioteca Virtual Miguel de Cervantes.

Colmenares, G. (1979). Factores de la vida política colonial: el Nuevo Reino de Granada en el siglo XviII. En Nueva Historia de Colombia (Vol. 14, pp. 386-415). Bogotá: s. e.

Córdoba, L. (2018). Los altos precios de la vida en los puertos del Caribe, los cortos salarios de los oficiales y la justificación velada de los fraudes a la corona en las primeras décadas del siglo XVII. En F. Andújar-Castillo y P. Ponce (eds.), Debates sobre la corrupción en el mundo ibérico, siglos XVI-XVIII (pp. 229-239). Alicante: Biblioteca Virtual Miguel de Cervantes.

Cruz, Ó. (2004). Historia del derecho en México. México: Oxford University Press.

Elliott, J. H. (2006). Imperios del mundo atlántico: España y Gran Bretaña en América, 1492-1830 (M. Balcells, Trad.). Madrid: Taurus.

Fajardo, L. E. (2002). La corrupción heredada: Pasado colonial, sistema legal y desarrollo económico en Colombia. Revista de Estudios Sociales, (12), 22-30. Dor: 10.7440/res 12.2002 .02

Galindo, J. (2021). Ethnic entrepreneurs, crony capitalism, and the making of the Franco-Mexican elite. Tuscaloosa: The University of Alabama Press.

Haber, S. H. (ed.). (2002). Crony capitalism and economic growth in Latin America: Theory and evidence. Stanford: Hoover Institution Press.

Imízcoz, J. M. (1996). Comunidad, red social y élites: Un análisis de la vertebración social en el Antiguo Régimen. En J. M. Imízcoz (ed.), Elites, poder y red social: Las élites del país Vasco y Navarra en la Edad Moderna: Estado de la cuestión y perspectivas (pp. 13-50). Bilboa: Universidad del País Vasco.

Jiménez, I. (2019). Poder, redes y corrupción en Perú (1660-1705). Sevilla: Editorial Universidad de Sevilla.

Kocka, J. (2016). Capitalism: A Short History. Princeton: Princeton University Press.

Laon, A. de (998). Carmen ad Robertum regem francorum. En Iglesias, T. (14 de junio, 2018). De la sociedad trinitaria medieval y la herencia de clases. Culturamas, la Revista de Información Cultural en Internet. Recuperado de https://www.culturamas.es

Maddison, A. (1986). Las fases del desarrollo capitalista: Una historia económica cuantitativa. México: Fondo de Cultura Económica.

Mauro, F. (1955). Pour une théorie du capitalisme commercial. Vierteljahrschrift für Sozial- und Wirtschaftsgeschichte, 42(2), 117-121.

McFarlane, A. (1997). Colombia ante de la independencia: Economía, sociedad, y política bajo el dominio borbón. Bogotá: Banco de la República/El Ancora Editores.

Mijangos, P. (2019). Historia mínima de la Suprema Corte de Justicia de México. México: El Colegio de México.

Miranda, H. (2015). La importancia de San Agustín y Santo Tomás de Aquino en la concepción cósmica y su influencia en los calendarios | Revista humanidades. Revista Humanidades, 5(2), $1-21$. 
Miranda, P. y Zabala, P. (2016). La conspiración de los capitulares: Poder y corrupción en la villa de Campeche, en la Nueva España, en el siglo xvir. En F. Andújar-Castillo y P. Ponce (eds.), Debates sobre la corrupción en el mundo ibérico, siglos XVI-XVIII (pp. 177-191). Alicante: Biblioteca Virtual Miguel de Cervantes. Recuperado de http://www.cervantesvirtual.com/obra/debatessobre-la-corrupcion-en-el-mundo-iberico-siglos-xvi-xviii-928763/

Moranchel, M. (2017). Compendio de Derecho romano. México: Universidad Autónoma Metropolitana.

Morineau, M. (2003). Introducción al sistema de common law. En P. Kurczyn (ed.), Hacia un nuevo derecho del trabajo (pp. 7-19). México: Universidad Nacional Autónoma de México.

North, D. C. (1990). Institutions, institutional change and economic performance. Cambridge: Cambridge University Press. doi: 10.1017/CBO9780511808678

North, D. C. y Thomas, R. P. (1973). The rise of the Western world: A new economic history. Cambridge: Cambridge University Press.

Nye, J. (1967). Corruption and political development: A cost-benefit analysis. The American Political Science Review, 61(2), 417-427.

Opheim, C. (1991). Explaining the differences in State lobby regulation. The Western Political Quarterly, 44(2), 405-421. Dor: 10.2307/448785

Orellana, J. C. (2019). De la crítica a la reforma. Pensamiento político, económico, y visión de reino en las denuncias indianas de corrupción (s. XVII). Historia y Memoria, 19, 67-120. DOI: 10.19053/20275137.n19.2019.8524

Pacheco, J. F., Cárdenas, F. y Torres de Mendoza, L. (1883). Colección de documentos inéditos relativos al descubrimiento, conquista y organización de las antiguas posesiones españolas en América y Oceanía (Vol. 39). Madrid: Imprenta de M. Bernaldo de Quirós. Recuperado de http://bibliotecadigi tal.aecid.es/bibliodig/es/consulta/registro.cmd?id=1118

Pagden, A. (1997). Señores de todo el mundo: Ideologías del imperio en España, Inglaterra y Francia (en los siglos XVI, XVII y XVIII). Barcelona: Península.

Pastor, R. (2002). El repartimiento de mercancías y los alcaldes mayores novohispanos: Un sistema de explotación, de sus orígenes a la crisis de 1810. En W. Borah (ed.), El gobierno provincial en la Nueva España: 1570-1787 (pp. 219-258). México: Universidad Nacional Autónoma de México.

Paxman, A. (2017). Simbiosis imperativa y conveniente. La evolución del capitalismo de cuates en Puebla, 1920-1940. Istor, 68, 29-54.

Peña, S. (1991). La formación del capitalismo en México. México: Siglo Veintiuno.

Pérez, P. (1991). Los beneficiarios del reformismo borbónico: Metrópoli versus élites novohispanas. Historia Mexicana, 41(2), 207-264.

Pietschmann, H. (1982). Burocracia y corrupción en Hispanoamérica colonial: Una aproximación tentativa. Nova Americana, 5, 11-37.

Pietschmann, H. (1996). Las reformas borbónicas y el sistema de intendencias en Nueva España: Un estudio político administrativo. México: Fondo de Cultura Económica.

Pietschmann, H. (1998). Corrupción en las Indias españolas: Revisión de un debate en la historiografía sobre Hispanoamérica colonial. Memorias de la Academia Mexica de la Historia. Correspondiente de la Real de Madrid, 40, 31-52. México. Recuperado de https://dialnet.unirioja.es/servle $\mathrm{t} /$ articulo? codigo $=2226639$ 
Ragon, P. (2018). Entre reyes, virreyes y obispos, la "corrupción” en debate (Nueva España, siglo XVII). En Debates sobre la corrupción en el mundo ibérico, siglos XVI-XVIII (pp. 17-30). Alicante: Biblioteca Virtual Miguel de Cervantes.

Rojas, B. (2007). Los privilegios como articulación de un cuerpo político. En Cuerpo político y pluralidad de derechos: Los privilegios de las corporaciones novohispanas (pp. 45-84). México: Instituto de Investigaciones Dr. José María Luis Mora/Centro de Investigación y Docencia Económicas.

Root, H. L. (1994). Fountain of Privilege: Political foundations of markets in old regime france and england. Place of publication not identified: University of California Press.

Rosales, C. M. (2016). Lobby y poder público: Una propuesta para la regulación del cabildeo. Revista de la Facultad de Derecho de México, 67(266), 347-388. Dor: 10.22201/fder.24488933e.20 16.266 .59010

Rosenmüller, Ch. (2016). De lo innato a lo performativo: Dos conceptos rivales de la corrupción, siglos XVII y xviII. En Ch. Rosenmüller y S. Ruderer (Eds.), "Dádivas, dones y dineros. ${ }^{A}$ portes a una nueva historia de la corrupción en América Latina desde el imperio español a la modernidad (pp. 61-85). Madrid-Frankfurt am Main: Iberoamericana/Vervuert.

Rosenmüller, Ch. y Ruderer, S. (eds.). (2016). "Dádivas, dones y dineros. ${ }^{A}$ portes a una nueva historia de la corrupción en América Latina desde el imperio español a la modernidad. Madrid-Frankfurt am Main: Iberoamericana/Vervuert.

Rucquoi, A. (2014). Entre la espada, el arado y la patena: Las tres órdenes en la España medieval. Dimensões, 13-14(33), 10-35.

Sánchez, E. (2016). Las reformas borbónicas como categoría de análisis en la historiografía institucional, económica y fiscal sobre Nueva España: Orígenes, implantación y expansión. Historia Caribe, 11(29), 19-51. Dor: 10.15648/hc.29.2016.3

Semo, E. (1985). Historia del capitalismo en México: Los orígenes, 1521 - 1763. México: Era.

Souto, M. (1990). Los consulados de comercio en Castilla e Indias: Su establecimiento y renovación (1494-1795). Anuario Mexicano de Historia del Derecho, 1(2), 227-250.

Souto, M. (2006). Creación y disolución de los consulados de comercio de la Nueva España. Revista Complutense de Historia de América, 32, 19-39.

Stein, S. J. (1981). Bureaucracy and Business in the Spanish Empire, 1759-1804: Failure of a Bourbon Beform in Mexico and Peru. Hispanic American Historical Review, 61(1), 2-28. DoI: 10.1215/00182168-61.1.2

Stein, S. J. (1982). Stanley J. Stein's Reply. Hispanic American Historical Review, 62(3), 469-477. DOI: $10.1215 / 00182168-62.3 .469$

Stein, S. J. y Stein, B. H. (1970). The colonial heritage of Latin America: Essays on economic dependence in perspective. Oxford: Oxford University Press.

Tovar, H. (1982). El Estado colonial frente al poder local y regional. Nova Americana, 5, 39-77.

Traslosheros, J. (1994). Estratificación social en el reino de la Nueva España, siglo Xvir. Relaciones. Estuidos de Historia y Sociedad, 59, 45-64.

Valle, G. del (2007). Cuerpo político y pluralidad de derechos: Los privilegios de las corporaciones novohispanas. Mexico: Centro de Investigación y Docencia Economicas/Instituto Mora.

Valle, G. del (2012). Finanzas piadosas y redes de negocios: Los mercaderes de la Ciudad de México ante la crisis de Nueva España, 1804-1808. México: Instituto de Investigaciones Dr. José María Luis Mora. 
Villarreal, A. (2018). Ejemplaridad e imitación: Reflexiones acerca de los remedios contra la corrupción en la monarquía hispánica. En F. Andújar-Castillo y P. Ponce (eds.), Debates sobre la corrupción en el mundo ibérico, siglos XVI-XVIII (pp. 353-362). Alicante: Biblioteca Virtual Miguel de Cervantes.

Villoro, L. (1994). La revolución de independencia. México: El Colegio de México. 